\title{
WODY LECZNICZE JAKO PODSTAWA ROZWOJU TURYSTYKI UZDROWISKOWEJ (NA PRZYKŁADZIE UZDROWISKA SOPOT)
}

\section{Wstęp}

Ze względu na wzrost świadomości i dbałości człowieka o własne zdrowie ważny segment współczesnego rynku turystycznego stanowi turystyka zdrowotna. Poziom zamożności społeczeństwa, zachorowalność oraz obecny w dzisiejszych czasach stres i pośpiech sprawiają, że ludzie są zmuszeni do poszukiwania równowagi wewnętrznej. Powoduje to zwiększenie zapotrzebowania na pobyt $\mathrm{w}$ uzdrowiskach, które dają możliwość przeniesienia się $\mathrm{w}$ inne miejsce i przebywania $\mathrm{w}$ odmiennym środowisku, w którym możliwe jest działanie wielu bodźców na organizm (Kaczmarska, 2010). Jedną ze specyficznych form turystyki zdrowotnej ze względu na jej główne cele (leczenie schorzeń oraz poprawa ogólnego stanu zdrowia) jest turystyka uzdrowiskowa (Mika, Ptaszycka-Jackowska, 2011).

Turystykę uzdrowiskową określa się jako wyjazdy związane z kuracją sanatoryjną, rehabilitacyjną i lecznictwem uzdrowiskowym, powiązane z zabiegami przyrodoleczniczymi, wykonywanymi po konsultacji z lekarzem uzdrowiskowym (Januszewska, 2004). Jej punktem docelowym jest uzdrowisko (obszar, na którym prowadzi się lecznictwo uzdrowiskowe), wydzielone w celu ochrony naturalnych surowców leczniczych, tj. wody, gazów, torfów (zwanych borowinami), oraz leczniczych właściwości klimatu (Bańkowska, 1999). Podczas kuracji uzdrowiskowych stosuje się balneoterapię, hydroterapię, klimatoterapię, fizykoterapię, kinezyterapię, masaże, farmakoterapię oraz metody z zakresu dietetyki czy psychoterapii. 
Głównymi zaletami lecznictwa uzdrowiskowego są: dobra tolerancja przez chorych, długo utrzymujący się efekt leczniczy oraz stosunkowo niewielki koszt. Ważnym elementem tego typu leczenia jest przebywanie na terenie miejscowości o lokalnym leczniczym klimacie (Drobnik, Malcewicz, Józefowski, Kurpas, Steciwko, 2011).

Istotny jest również fakt, że lecznictwo uzdrowiskowe stanowi integralną część systemu ochrony zdrowia, jako że spełnienia wiele zadań, tj.: leczenie schorzeń przewlekłych, rehabilitacja (m.in. wodolecznictwo, hydroterapia), profilaktyka zdrowotna oraz edukacja i promocja zdrowia (Krupa, Wołowiec, 2010). W świetle dokumentów Światowej Organizacji Zdrowia (World Health Organization - WHO) profilaktyka zdrowotna została uznana za przyszłość lecznictwa, jako że na każdym etapie naturalnej historii choroby możliwe są działania zapobiegawcze na wszystkich poziomach (Woźniak-Holecka, Holecki, 2012).

W Rzeczypospolitej w XVIII w. wiele osób cierpiało na przewlekłe i nieuleczalne choroby, w których obliczu polska medycyna okazywała się bezradna. Bardzo modnym sposobem kuracji na różnorodne schorzenia stawały się wówczas wyjazdy do ciepłych źródeł wód mineralnych. Do końca XVIII w. kąpiele lecznicze i picie wody mineralnej były właściwie jedynymi praktykami z dziedziny polskiej balneologii (Kucharski, 2010). Obecnie za najlepszą formę fizjoterapii uznawana jest balneoterapia. Jest ona stosowana w każdej fazie postępowania lekarskiego w zapobieganiu chorobom, leczeniu ich oraz profilaktyce zdrowotnej. Zakres zabiegów z dziedziny balneoterapii jest bardzo szeroki. Do najpowszechniej stosowanych należą: kąpiele mineralne, kuracja pitna oraz inhalacje. Wody mineralne, jak podkreśla się w literaturze przedmiotu, są jednymi z najważniejszych naturalnych surowców leczniczych (Hadzik, 2011).

Celem niniejszego artykułu jest charakterystyka wykorzystania solanki przez Zakład Balneologiczny w Sopocie, mieszczący się na terenie Pomorskiego Centrum Reumatologicznym im. dr Jadwigi Titz-Kosko w Sopocie. Tekst powstał na podstawie danych udostępnionych przez obiekt.

\section{Charakterystyka miasta Sopotu jako uzdrowiska}

Sopot to miasto na prawach powiatu, położone $\mathrm{w}$ województwie pomorskim, nad Zatoką Gdańską, w aglomeracji trójmiejskiej, którą tworzy wraz z Gdańskiem i Gdynią. Obejmuje obszar o powierzchni $17 \mathrm{~km}^{2}$, a ponad połowę tego terenu (około 61,2\% powierzchni) zajmują lasy, w więk- 
szości położone w Trójmiejskim Parku Krajobrazowym, oraz parki i zieleńce. Rzeźbę terenu miasta uatrakcyjnia pasmo dolin ukształtowanych wzdłuż potoków, prostopadle do brzegu morza. Wzdłuż wybrzeża Zatoki Gdańskiej rozciąga się plaża, oddzielona od zbudowań miejskich terenami parkowymi i pasem wydm (Studium uwarunkowań..., 2018).

Miasto ma bogatą ofertę i infrastrukturę wypoczynkową, kulturalną i rekreacyjną, do których zaliczane są m.in. obiekty sportowe, takie jak: ośrodek sportów jeździeckich, zespół kortów tenisowych, aquapark czy wielofunkcyjna hala widowiskowo-sportowa Ergo Arena (zlokalizowana na granicy z Gdańskiem). Ponadto znajdują się tam kluby żeglarskie oraz marina - przystań jachtowa. Należy tu wymienić również obiekty stanowiące symbol Sopotu, tj. Operę Leśną, Grand Hotel z zapleczem kuracyjnym oraz molo spacerowe. Naturalne bogactwo Sopotu to przede wszystkim plaże z przyległymi parkami, nadmorski klimat, atrakcyjna lokalizacja, rozległe tereny zielone oraz źródło leczniczej wody mineralnej.

Sopot stał się miejscowością kąpieliskowo-uzdrowiskową w momencie powstania zakładu kąpielowego w 1823 r. Rok później wzniesiono tu pierwszy dom kuracyjny, a w $1825 \mathrm{r}$. rozpoczęto prace nad urządzeniami parku zdrojowego (Mamuszka, 1981). Doprowadzenie kolei żelaznej w 1870 r. przyczyniło się do niezwykle dynamicznego rozwoju kąpieliska - Sopot $\mathrm{z}$ niewielkiego ośrodka o lokalnym znaczeniu w krótkim czasie zmienił się w nowoczesny, elegancki i wytworny kurort (Michałowski, Tobis, 2010). W 1972 r. potwierdzono tu występowanie wody 4,4\% chlorkowo-sodowej, bromkowej, jodkowej, borowej przy samowypływie, po wykonanym odwiercie solanki Sopot JG-1 i temperaturze $16,5^{\circ} \mathrm{C}$. Oficjalnie Sopot uzyskał status uzdrowiska dopiero w 1999 r. (Uchwata, 2010).

Obecnie na terenie Sopotu znajduje się pięć zakładów lecznictwa uzdrowiskowego:

- Niepubliczny Zakład Opieki Zdrowotnej Sanatorium Uzdrowiskowe „Kamienny Potok”,

- Samodzielny Publiczny Zakład Opieki Zdrowotnej Sanatorium Uzdrowiskowe Ministerstwa Spraw Wewnętrznych i Administracji,

- Sanatorium Uzdrowiskowe "Leśnik",

- Sanatorium Uzdrowiskowe „Perła”,

- Pomorskie Centrum Reumatologiczne im. dr Jadwigi Titz-Kosko w Sopocie (wraz z mieszczącym się tam Zakładem Balneologicznym).

Wykorzystanie bogactw naturalnych w celach leczniczych jest możliwe dzięki urządzeniom lecznictwa uzdrowiskowego, tworzącym specyficzną infrastrukturę. W Sopocie wyróżnia się plażę nadmorską (o długości $400 \mathrm{~m}$ 
- odcinek dostosowany do potrzeb osób niepełnosprawnych i zaopatrzony w toalety) oraz wizytówkę miasta - molo, które dzięki swojej konstrukcji jest osłonięte od wiatrów z kierunku wschodniego i północno-wschodniego oraz znajduje się w zasięgu aerozoli wody morskiej. Wśród ogólnodostępnych urządzeń specjalistycznych, umożliwiających wykorzystywanie solanki, w Sopocie zlokalizowane są pijalnie wody mineralnej, mieszczące się przy Zakładzie Balneologicznym (fot. 1) oraz na trzecim piętrze Domu Zdrojowego. W pijalni znajduje się jedna wylewka z zawartością 4,2\% wody chlorkowo-sodowej, jodkowej ze Zdroju św. Wojciecha oraz siedem wylewek z wodą 15-krotnie rozcieńczoną (0,3\%) (Krupa, Naperała, 2014).

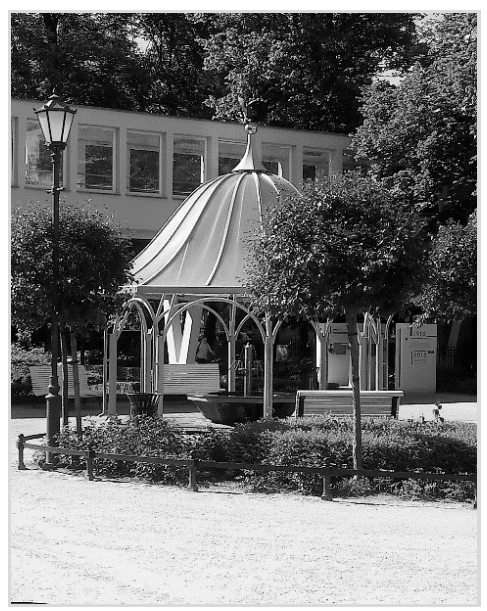

Fot. 1. Pijalnia wody mineralnej przy Zakładzie Balneologicznym w Sopocie Źródło: M. Sywula

Kolejnym urządzeniem wykorzystującym sopocką solankę jest grzybek inhalacyjny (fot. 2). Znajduje się on w środkowej części parku Południowego i służy do inhalacji przy przewlekłych chorobach zapalnych i schorzeniach alergicznych dróg oddechowych.

W 2018 r. na terenie ośrodka żeglarskiego w Sopocie wybudowano tężnię solankową (fot. 3). Sopocka tężnia ma kształt walca o wysokości $4 \mathrm{~m}$ i średnicy $2,5 \mathrm{~m}$. Zbudowana jest $\mathrm{z}$ drewna i zasilana solanką ze Zdroju św. Wojciecha. Tężnia działa w obiegu częściowo zamkniętym, co oznacza, że jest zasilana nową solanką w miejsce tej, która odparowuje. Po tarninie spływa woda, tworząc aerozol dający uczucie chłodu, dlatego jest to 
idealne miejsce do spędzania czasu w upalne dni. Wokół tężni ustawione są ławki, na których można posiedzieć i wypocząć, jednocześnie się inhalując. Tężnia jest ogólnodostępna i darmowa. Sprzyja osobom z astmą oraz chorobami skóry.

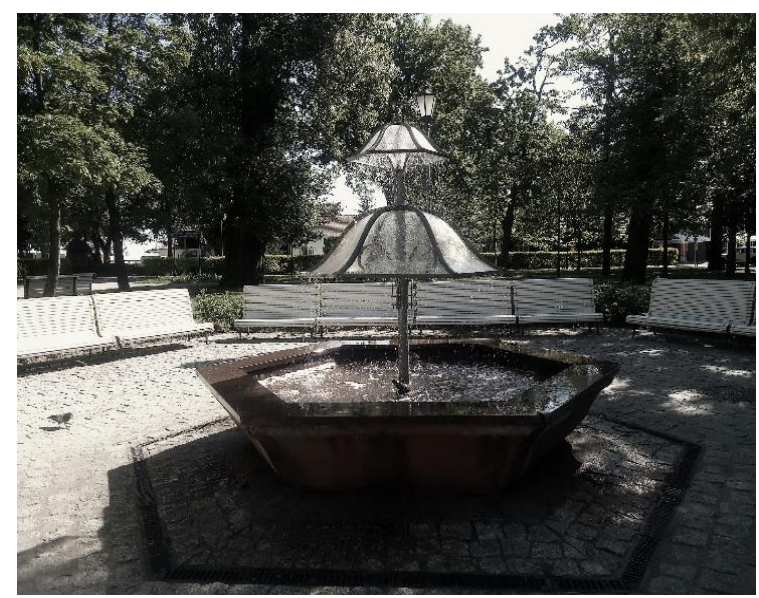

Fot. 2. Grzybek inhalacyjny w Sopocie Źródło: M. Sywula

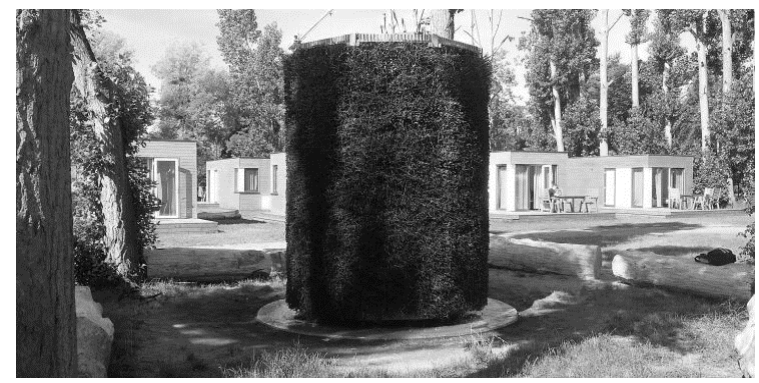

Fot. 3. Tężnia solankowa w Sopocie na terenie ośrodka żeglarskiego Źródło: Powstała pierwsza tężnia solankowa w Sopocie... (2018)

\section{Wody lecznicze i ich wykorzystanie w Zakładzie Balneologicznym w Sopocie}

Wody lecznicze powstają wskutek wypłukiwania przez wody infiltracyjne składników mineralnych ze skał lub są produktami reakcji, które zachodzą pomiędzy składnikami chemicznymi. W momencie zetknięcia się 
wody infiltracyjnej z pokładami mineralnymi przechodzą do wody zawarte w nich składniki łatwo w niej rozpuszczalne. Gazy dostają się do wody na skutek różnych procesów zachodzących w głębi ziemi. Najważniejsze spośród tych gazów to: dwutlenek węgla, siarkowodór i radon. Wskutek zakwaszania wody przez dwutlenek węgla dostają się do niej słabo rozpuszczalne minerały. Dzięki takiemu procesowi woda jest wysoko zmineralizowana (Ponikowska, Ferson, 2009).

Według stanu na 31.12.2017 r. wody podziemne zaliczane do kopalin w Polsce zostały udokumentowane w około 480 ujęciach (studniach, głębokich otworach wiertniczych, źródłach, szybach, sztolniach oraz wypływach w wyrobiskach górniczych), zlokalizowanych w 131 miejscowościach. Łączne zasoby eksploatacyjne wód leczniczych, termalnych i solanek wynosiły nieco ponad 6 tys. $\mathrm{m}^{3} / \mathrm{h}$. Ich wydobycie od kilku lat utrzymuje się na poziomie ponad $12 \mathrm{mln}^{3} / \mathrm{r}$. (tab. 1).

Tab. 1. Wielkość zasobów eksploatacyjnych i wydobycia wód podziemnych w Polsce w latach 2015-2017

\begin{tabular}{|l|c|c|c|c|r|}
\hline \multirow{2}{*}{ Rodzaj wód } & \multicolumn{2}{|c|}{ Zasoby eksploatacyjne $\left(\mathrm{m}^{3} / \mathrm{h}\right)$} & \multicolumn{2}{c|}{ Wydobycie $\left(\mathrm{m}^{3} / \mathrm{r}.\right)$} \\
\cline { 2 - 6 } & 2015 & 2016 & 2017 & 2015 & \multicolumn{1}{c|}{2016} \\
\hline Wody lecznicze & 1674,8 & 1631,89 & 1964,85 & 1998883,2 & 1964112,8 \\
\hline Wody termalne & 4839,4 & 4772,8 & 4044,30 & 10186935,0 & 10520347,4 \\
\hline Solanki & 3,7 & 3,7 & 3,7 & 3235,0 & 3178,8 \\
\hline Łącznie & 6517,9 & 6408,39 & 6012,85 & 12189071,2 & 12487639,0 \\
\hline
\end{tabular}

Źródło: opracowanie własne na podstawie: Felter i in. (2017a, 2017b, 2018).

Wody chlorkowo-sodowe, jodkowe (solanki) to takie wody, które zawierają powyżej $15 \mathrm{~g} / 1$ chlorku sodu lub powyżej $35 \mathrm{~g} / \mathrm{dm}^{3}$ soli mineralnych. Ponadto $\mathrm{w}$ wodach tych występują także inne jony, tj. jodu, bromu czy żelaza. Działają one bakteriobójczo, przeciwzapalnie i mukolitycznie (upłynniają śluz $\mathrm{w}$ drogach oddechowych). Ponadto są wykorzystywane do produkcji soli leczniczej, a także do kąpieli, kuracji pitnych, inhalacji i irygacji. Aby móc korzystać z kopalin i wód leczniczych, termalnych i solanek w obrębie ustanowionych obszarów górniczych, uzdrowisko musi posiadać koncesję geologiczną. Solanki wykorzystywane są w następujących 16 uzdrowiskach w Polsce: Busku-Zdroju, Ciechocinku, Goczałkowicach-Zdroju, Inowrocławiu, Kamieniu Pomorskim, Kołobrzegu, Konstancinie-Jeziornie, Połczynie-Zdroju, Rabce-Zdroju, Solcu-Zdroju, Sopocie, Świnoujściu, Uniejowie, Ustce, Ustroniu i Wieńcu-Zdroju (Koźmiński, 2016). 
W Sopocie do celów leczniczych wykorzystywana jest solanka o stężeniu 4,4\%, wypływająca samoistnie ze Zdroju św. Wojciecha na głębokości $839 \mathrm{~m}$. Zasoby eksploatacyjne przy samowypływie wynoszą $44,0 \mathrm{~m}^{3} / \mathrm{h}$. Uzdrowisko Sopot posiada koncesję na wydobycie wód leczniczych ważną do 19.10.2024 r. Solanki używa się we wszystkich obiektach lecznictwa uzdrowiskowego znajdujących się w Sopocie. Procesowi wykorzystania solanki przyjrzano się w Zakładzie Balneologicznym, w którym wykonuje się gimnastykę $\mathrm{w}$ basenie solankowym oraz kąpiele solankowe.

W 2017 r. ze wszystkich zabiegów oferowanych w Zakładzie Balneologicznym w Sopocie (m.in. hydroterapia, zabiegi borowinowe, inhalacje) skorzystało około 140 tys. osób, w tym 30 tys. mężczyzn i 110 tys. kobiet. Wysoki - prawie 80-procentowy - udział przedstawicielek płci żeńskiej wynika z faktu, że kobiety na ogół bardziej niż mężczyźni interesują się własnym stanem zdrowia. Przywiązywanie przez kobiety dużej wagi do zdrowia wiąże się z ich większą podatnością na choroby, dbałością o swoją kondycję fizyczną oraz o młody wygląd. Wskazuje się, że wynika to $\mathrm{z}$ narażenia kobiet na społeczny stres związany m.in. $\mathrm{z}$ obciążeniem obowiązkami domowymi, których wykonywanie często jest niedoceniane, problemami finansowymi i brakiem satysfakcjonującej gratyfikacji za pracę zawodową (Malinowska, Dzwonkowska-Godula, Garncarek, Czernecka, Brzezińska, 2016).

Na zabiegi hydroterapeutyczne do Zakładu Balneologicznego w Sopocie przybywa rocznie około 46 tys. osób (tab. 2, rys. 1). Stanowią one 11,2\% wszystkich korzystających z oferty tego zakładu w 2017 r.

Tab. 2. Liczba osób korzystających z zabiegów wodoleczniczych w Zakładzie Balneologicznym w Sopocie w latach 2016-2017

\begin{tabular}{|l|r|r|}
\hline \multirow{2}{*}{ Rodzaj zabiegu } & \multicolumn{2}{|c|}{ Rok } \\
\cline { 2 - 3 } & 2016 & 2017 \\
\hline Gimnastyka w basenie solankowym & 20265 & 19687 \\
\hline Kąpiele solankowe & 4016 & 4199 \\
\hline Kąpiele kwasowęglowe & 7168 & 7769 \\
\hline Hydromasaż & 5491 & 5373 \\
\hline Kąpiele wirowe & 7075 & 7152 \\
\hline Masaż podwodny & 1780 & 1966 \\
\hline Bicze szkockie & 271 & 329 \\
\hline
\end{tabular}

Źródło: opracowanie własne na podstawie danych udostępnionych przez Pomorskie Centrum Reumatologiczne im. dr Jadwigi Titz-Kosko w Sopocie. 


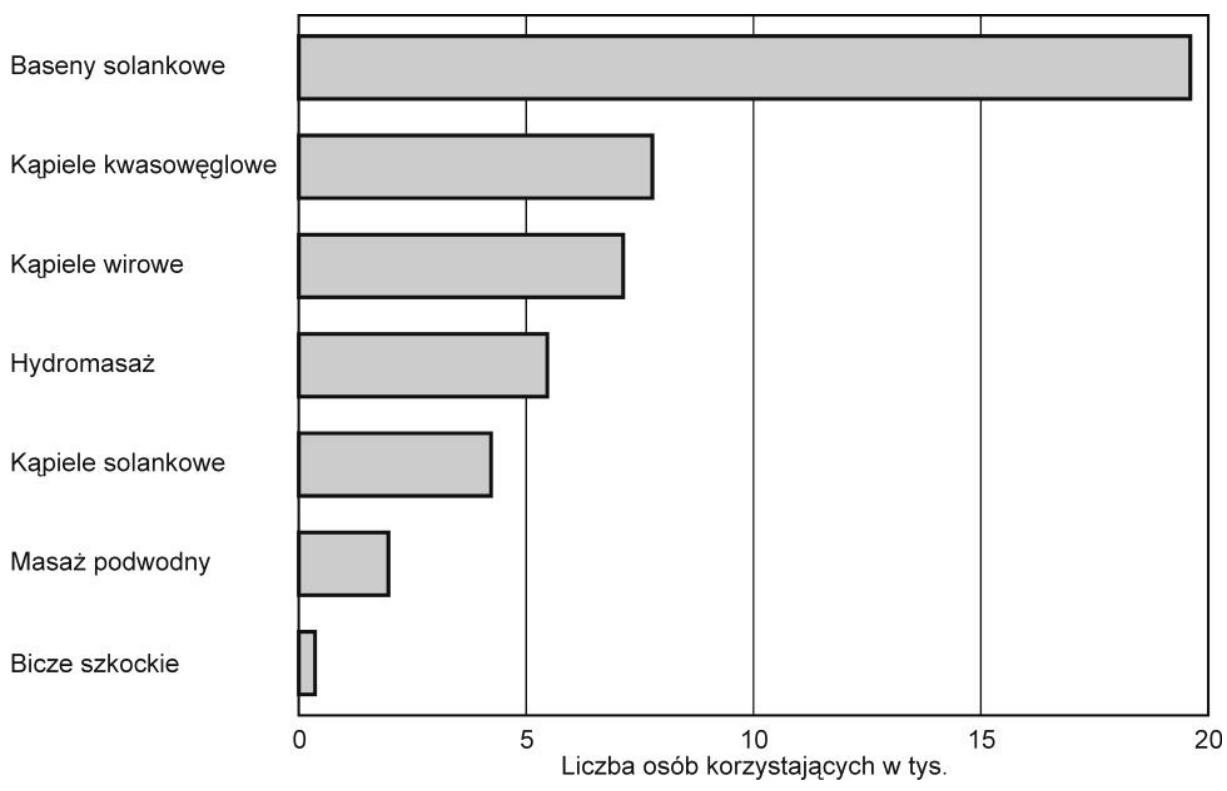

Rys. 1. Struktura wykorzystania zabiegów hydroterapeutycznych w Zakładzie Balneologicznym w Sopocie w 2017 r.

Źródło: opracowanie własne na podstawie danych udostępnionych przez Pomorskie Centrum Reumatologiczne im. dr Jadwigi Titz-Kosko w Sopocie

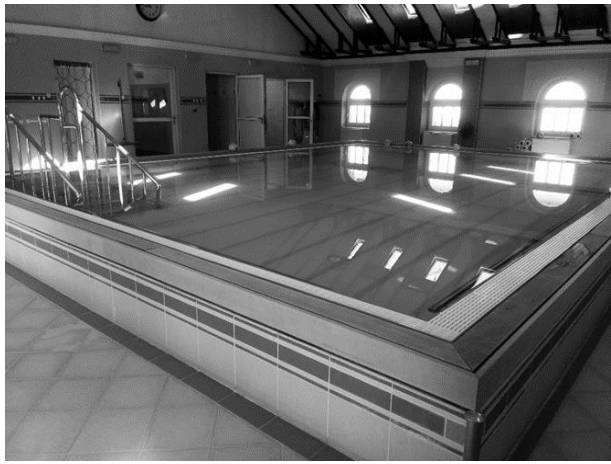

Fot. 4. Basen solankowy w Zakładzie Balneologicznym w Sopocie Źródło: M. Sywula

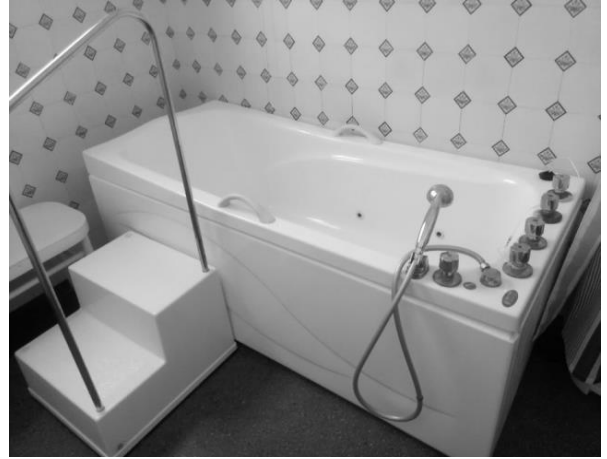

Fot. 5. Wanna do kąpieli solankowej w Zakładzie Balneologicznym w Sopocie Źródło: M. Sywula

Najpopularniejszym zabiegiem $\mathrm{w}$ obiekcie jest gimnastyka $\mathbf{w}$ basenie solankowym (fot 4). W 2017 r. tej formie leczenia poddano 19687 osób, co stanowi $42,7 \%$ kuracjuszy stosujących hydroterapię i $4,8 \%$ wszystkich pa- 
cjentów Zakładu Balneologicznego w Sopocie. W 2016 r. z gimnastyki w basenie solankowym skorzystało 20265 osób, czyli o 1,3\% więcej niż w 2017 r.

Solanka w Zakładzie Balneologicznym w Sopocie używana jest również do kąpieli w wannach (fot. 5). W 2017 r. z kąpieli solankowej skorzystało 4199 kuracjuszy. Stanowili oni 9,1\% osób przychodzących na zabiegi hydroterapeutyczne i 1\% wszystkich pacjentów Zakładu Balneologicznego w Sopocie. W 2016 r. z kąpieli solankowej skorzystało 4016 osób, co stanowiło $8,7 \%$ pacjentów przychodzących na zabiegi hydroterapeutyczne do Zakładu Balneologicznego, tj. o 0,4\% mniej niż w 2017 r.

W Zakładzie Balneologicznym w Sopocie oferowane są również dodatkowe zabiegi z zakresu hydroterapii, do których nie wykorzystuje się solanki, ale które służą poprawie zdrowia dzięki wykorzystaniu leczniczych właściwości wody. Są to:

- kąpiele kwasowęglowe kończyn górnych i dolnych,

- kąpiele wirowe kończyn górnych i dolnych,

- kąpiele wirowe kręgosłupa,

- hydromasaż,

- masaż podwodny,

- bicze szkockie.

Kąpiele kwasowęglowe wykonywane są w wodzie zawierającej rozpuszczony dwutlenek węgla. Działanie lecznicze zabiegu zależy od ilości rozpuszczonego dwutlenku węgla, ciśnienia i temperatury wody oraz jej rodzaju i ilości innych składników. Kąpiel polega na zanurzeniu w wodzie jednej lub obydwu nóg (fot. 5), czy też rąk (fot. 6) w odpowiednio przystosowanych do tego wannach. W 2017 r. zabiegowi na kończyny dolne

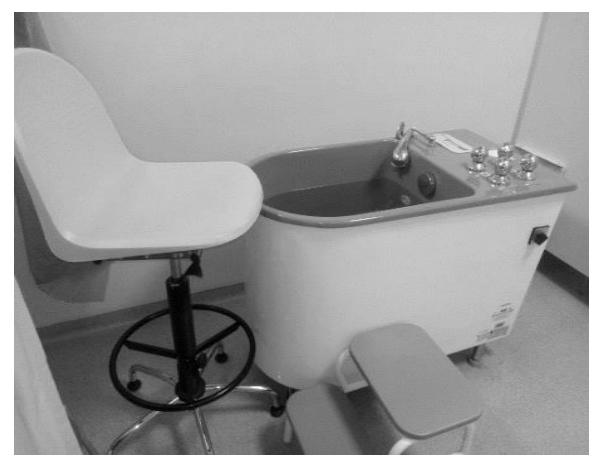

Fot. 6. Wanna do kwasowęglowych kąpieli kończyn dolnych w Zakładzie Balneologicznym w Sopocie Źródło: M. Sywula

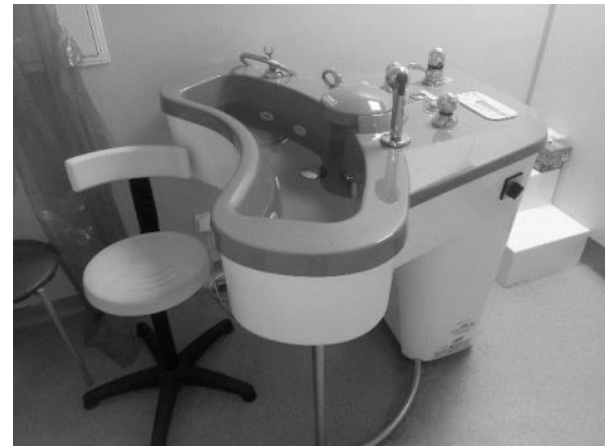

Fot. 7. Wanna do kwasowęglowych kąpieli kończyn górnych w Zakładzie Balneologicznym w Sopocie Źródło: M. Sywula 
zostało poddanych 4774 kuracjuszy, a na kończyny górne - 2994. Łącznie w 2017 r. z kąpieli kwasowęglowej w Zakładzie Balneologicznym w Sopocie skorzystało 7769 osób. Stanowili oni $16,8 \%$ pacjentów, którzy zdecydowali się na zabiegi hydroterapeutyczne i 1,9\% wszystkich osób przychodzących do Zakładu. W 2016 r. z zabiegu na kończyny górne skorzystało 3889 osób, a na kończyny dolne - 3279, tj. o 1,3\% mniej niż w 2017 r.

Kąpiele wirowe służą do podwodnych masaży kończyn dolnych lub górnych i są wykonywane w wannach, które wywołują ruch wirowy wody. W 2017 r. z zabiegu na kończyny dolne skorzystało 4078 kuracjuszy, a na górne - 3074. Łącznie kąpiele wirowe w Zakładzie Balneologicznym w Sopocie odbyło 7152 osoby. Stanowili oni 15,5\% pacjentów poddanych zabiegom hydroterapeutycznym i 1,7\% wszystkich kuracjuszy leczących się w Zakładzie Balneologicznym w Sopocie. W 2016 r. z zabiegu na kończyny górne skorzystały 3662 osoby, a na kończyny dolne - 3413, czyli łącznie o 0,2\% mniej wszystkich kuracjuszy poddawanych zabiegom hydroterapeutycznym niż w 2017 r. w Zakładzie Balneologicznym w Sopocie.

Hydromasaż wykonuje się na całe ciało $\mathrm{w}$ wannie wyposażonej $\mathrm{w}$ specjalne dysze, z których wypompowywana jest woda pod odpowiednim ciśnieniem. Z tego zabiegu w 2017 r. skorzystały 5373 osoby. Stanowiły one $11,6 \%$ pacjentów przychodzących na zabiegi hydroterapeutyczne i 1,3\% wszystkich kuracjuszy leczących się w Zakładzie Balneologicznym w Sopocie. W 2016 r. na hydromasaż zdecydowało się 5491 osób, czyli o 0,3\% więcej niż w $2017 \mathrm{r}$.

Masaż podwodny wykonywany jest na konkretną część ciała przez terapeutę w wannie, która umożliwia pełen zakres ruchów. W 2017 r. na tego typu masaż zdecydowało się 1966 kuracjuszy. Stanowili oni 4,2\% osób poddawanych zabiegom hydroterapeutycznym i 0,4\% wszystkich korzystających z zabiegów w Zakładzie Balneologicznym w Sopocie. W 2016 r. masaż wodny wykonano u 1780 osób, czyli u 3,8\% korzystających z zabiegów hydroterapeutycznych.

Najmniej popularnym zabiegiem są bicze szkockie, z których w Zakładzie Balneologicznym korzysta niespełna 1\% kuracjuszy. Zabieg polega na smaganiu ciała strumieniem wody $\mathrm{w}$ specjalnym, wyłożonym kafelkami pomieszczeniu. W 2017 r. zabiegowi poddano 329 osób, w 2016 r. zaś - zalewie 271. 


\section{Podsumowanie i wnioski}

Turystyka uzdrowiskowa jest bardzo ważna w promowaniu zdrowego stylu życia. Sopot jako miejscowość uzdrowiskowa wyróżnia się naturalnym potencjałem, który umożliwia korzystanie z unikatowych produktów uzdrowiskowych, np. poprzez: balneoterapię, hydroterapię czy klimatoterapię. Ponadto jej walory przyrodnicze stanowią podstawowy zasób wykorzystywany do realizacji form turystyki wypoczynkowej. Ważnym bogactwem naturalnym Sopotu, na którym w dużej mierze opiera się oferta lecznicza, jest woda solanka wypływająca samoistnie ze Zdroju św. Wojciecha. Wykorzystuje się ją w tężniach, grzybkach inhalacyjnych w parkach sopockich czy do kuracji pitnej. Jak wynika z danych Zakładu Balneologicznego, specjalistycznym zabiegom z użyciem solanki, oferowanym przez Zakład, poddawanych jest rocznie około 24 tys. osób.

Władze miasta oraz inwestorzy zdają sobie sprawę z tego, jak istotna w Sopocie jest turystyka uzdrowiskowa. W związku z tym planowany jest dalszy rozwój infrastruktury, bazującej na naturalnych zasobach wód leczniczych. Jeden z pomysłów zakłada budowę przez miasto ogólnodostępnych basenów solankowych w pobliżu ośrodka żeglarskiego (teren nie został jeszcze sprzedany ani wydzierżawiony, obecnie na tym obszarze znajduje się minigolf). Ponadto do 2020 r. ma powstać nowe centrum uzdrowiskowe, stworzone przez Fundację „Sport Na Zdrowie”, mające pełnić funkcję specjalistycznego ośrodka rehabilitacyjnego dla dzieci, z basenami solankowymi, tężnią solankową oraz inhalatoriami.

\section{Bibliografia}

Bańkowska, E. (1999). Szanse i zagrożenia Sopotu jako miejscowości uzdrowiskowej. W: Boruszczak M. (red.), Turystyka uzdrowiskowa. Stan i perspektywy. Gdańsk: Publikacje Wyższej Szkoły Turystyki i Hotelarstwa w Sopocie.

Drobnik, J., Malcewicz, M,. Józefowski, P., Kurpas, D., Steciwko, A. (2011). Medycyna uzdrowiskowa - współczesne lecznictwo uzdrowiskowe w Polsce. Family Medicine E Primary Care Review, 13 (1), 103-108.

Felter, A., Skrzypczyk, L., Socha M., Sokołowski J., Sosnowska M., Stożek J., Gryszkiewicz I., Gryczko-Gostyńska, A. (2018). Mapa zagospodarowania wód podziemnych zaliczonych do kopalin w Polsce. Tekst objaśniający. 2017. Warszawa: Państwowy Instytut Geologiczny, Państwowy Instytut Badawczy.

Felter, A., Skrzypczyk, L., Socha M., Sokołowski J., Stożek J., Gryczko-Gostyńska, A. (2017a). Mapa zagospodarowania wód podziemnych zaliczonych do kopalin w Polsce. Tekst objaśniajacy. 2015. Warszawa: Państwowy Instytut Geologiczny, Państwowy Instytut Badawczy. 
Felter, A., Skrzypczyk, L., Socha M., Sokołowski J., Stożek J., Gryczko-Gostyńska, A. (2017b). Mapa zagospodarowania wód podziemnych zaliczonych do kopalin w Polsce. Tekst objaśniający. 2016. Warszawa: Państwowy Instytut Geologiczny, Państwowy Instytut Badawczy.

Hadzik, A., (2011). Turystyka i rekreacja uzdrowiskowa. Katowice: Akademia Wychowania Fizycznego im. Jerzego Kukuczki w Katowicach.

Januszewska, M., (2004). Konkurencyjność gmin uzdrowiskowych. Prace Naukowe Akademii Ekonomicznej we Wrocławiu, 1023, 188-200.

Kaczmarska, A. (2010). Uwarunkowania i tendencje zmian rozwoju uzdrowisk w Polsce. W: A.R. Szromek (red.), Uzdrowiska $i$ ich znaczenie w gospodarce turystycznej (s. 55-75). Kraków: Proksenia.

Koźmiński, C. (2016). Turystyka zdrowotna, uzdrowiskowa i uwarunkowania bioklimatyczne. Wydanie 2 rozszerzone. Szczecin: Wydawnictwo Naukowe Uniwersytetu Szczecińskiego.

Krupa, J., Wołowiec, T. (2010). Uzdrowiska Polski Wschodniej wobec wyzwań rozwojowych - turystyka zrównoważona. W: J. Hermaniuk, J. Krupa (red.), Wspótczesne trendy funkcjonowania uzdrowisk - klastering (s. 7-36). Rzeszów: Instytut Gospodarki Wyższej Szkoły Informatyki i Zarządzania w Rzeszowie.

Krupa, W.A., Naperała, J. (2014). Miasto Sopot. W: W.A. Krupa (red.), Sopockie sympozja (s. 121-135). Sopot: Wydawnictwo Samodzielny Publiczny Zakład Opieki Zdrowotnej "Uzdrowisko Sopot".

Kucharski, A. (2010). Staropolska turystyka uzdrowiskowa w XVIII wieku. Czasy Nowożytne, 23, 121-148.

Malinowska, E., Dzwonkowska-Godula, K., Garncarek, E., Czernecka, J., Brzezińska, J. (2016). Kulturowe uwarunkowania postaw kobiet $i$ mężczyzn w różnym wieku wobec swego wygladu i zdrowia. Łódź: Wydawnictwo Uniwersytetu Łódzkiego.

Mamuszka, F. (1981). Bedeker Sopocki. Gdańsk: Wydawnictwo Morskie.

Michałowski, L., Tobis, T. (2010). Sopot. Od elitarnego uzdrowiska do kurortu dla mas. Studia Socjologiczne, 3, 163-178.

Mika, M., Ptaszycka-Jackowska, D. (2011). Formy turystyki zdrowotnej. W: W. Kurek (red.), Turystyka (s. 279-291). Warszawa: Wydawnictwo Naukowe PWN.

Ponikowska, I., Ferson, D. (2009). Nowoczesna medycyna uzdrowiskowa. Warszawa: Medi Press.

Powstała pierwsza tężnia solankowa w Sopocie. „To taki grzybek inhalacyjny na sterydach" (2019). Pobrane z: https://radiogdansk.pl/wiadomosci/item/78034-powstala-pierwszateznia-solankowa-w-sopocie-to-taki-grzybek-inhalacyjny-na-sterydach-film (11.06.2018).

Studium uwarunkowań i kierunków zagospodarowania przestrzennego miasta Sopotu (2018). Pobrane z: https:// bip.sopot.pl/Article/id,183.html.

Uchwata nr XXXVI/429/2010 Rady Miasta Sopotu z dnia 5 marca 2010 r. w sprawie uchwalenia Statutu Uzdrowiska Sopot.

Woźniak-Holecka, J., Holecki, T. (2012). Profilaktyka i edukacja zdrowotna w leczeniu uzdrowiskowym. W: A.R. Szromek (red.), Uzdrowiska i ich funkcja turystyczno-lecznicza (s. 215-227). Kraków: Proksenia. 


\title{
WODY LECZNICZE JAKO PODSTAWA ROZWOJU TURYSTYKI UZDROWISKOWEJ (NA PRZYKŁADZIE UZDROWISKA SOPOT)
}

\begin{abstract}
Abstrakt: Stres i pośpiech, wszechobecne w życiu współczesnego człowieka, wpływają na zwiększenie zainteresowania pobytem $\mathrm{w}$ uzdrowiskach, dającym możliwość obcowania ze środowiskiem, w którym możliwe jest działanie wielu pozytywnych bodźców na organizm. Przedmiotem artykułu jest nadmorskie Uzdrowisko Sopot, słynące ze źródła wody mineralnej chlorkowo-sodowej, jodkowej i bromkowej, stosowanej w lecznictwie uzdrowiskowym. Do celów leczniczych (w tężniach, grzybkach inhalacyjnych oraz przy kuracji pitnej) wykorzystywana jest solanka o stężeniu $4,4 \%$. Woda ta stanowi podstawę zabiegów leczniczych wykonywanych m.in. w Zakładzie Balneologicznym w Sopocie.
\end{abstract}

Słowa kluczowe: uzdrowisko nadmorskie, wody lecznicze, hydroterapia, solanka.

\section{WATER TREATMENTS AS THE BASIS FOR THE DEVELOPMENT OF SPA TOURISM (SPA SOPOT CASE STUDY)}

\begin{abstract}
Stress and rush, ever-present in modern life, increase people's interest in health resorts, which give them an opportunity to get close to the natural environment. As a result, many positive stimuli have a beneficial effect on their bodies. The subject of the article is the seaside health resort of Sopot, famous for being a source of curative sodium chloride, iodine and bromide mineral water, used in health resort treatments. The $4.4 \%$ brine is used for treatment in graduation towers, inhalation mushrooms in Sopot parks or in the form of drinking cure. It is the basis of medical treatments conducted, among others, at the Zakład Balneologiczny (Balneology Centre) in Sopot.
\end{abstract}

Keywords: seaside health resort, healing waters, hydrotherapy, brine. 